\title{
Efektivitas Pupuk Organik pada Tumpangsari Kedelai dengan Jagung untuk Mengurangi Penggunaan Pupuk N, P dan K
}

\section{Effectiveness of Organic Fertilizer on Soybean and Corn Intercropping to Reduce Utilization of $\mathrm{N}, \mathrm{P}$ and $\mathrm{K}$}

\author{
Evi Oktanika ${ }^{1)}$, Supriyono ${ }^{2)}$, Suwarto $^{2)}$
}

\begin{abstract}
Soybean is one of the commodity with high market demand. Soybean production process is limited by the lack of land. One of the efforts to improve the usefullness of land and production of soybean is an intercropping method between soybean and corn. Intercropping that over using chemical fertilizers have impact negatively on the land. Therefore, utilization of organic fertilizer to reduce the chemical fertilizer is necessary to prevent the damage of the land. This study aimed to examine the utilization of organic fertilizer to replace a part of chemical fertilizer. This study was conducted at the Center for Dryland Research Faculty of Agriculture, University of Sebelas Maret Surakarta, Jumantono, Karanganyar started on February until May 2013. The experiment was conducted using Randomized Complete Block Design (RCBD) with one factor fertilization consists of 6 levels, one control and two comparators monoculture. The results showed that application of organic fertilizer $800 \mathrm{~kg}$ $\mathrm{ha}^{-1}$, Urea $125 \mathrm{~kg} \mathrm{ha}^{-1}, \mathrm{SP}-3683.33 \mathrm{~kg} \mathrm{ha}^{-1}$ and KCl $83.33 \mathrm{~kg} \mathrm{ha}^{-1}$ with the highest yield for soybean 1.52 tons $\mathrm{ha}^{-1}$ and corn 1.25 tons $\mathrm{ha}^{-1}$ is optimal balance dosage of organic and inorganic fertilizers to soybean-corn intercropping. The treatment did not significantly different with inorganic fertilizer intercropping experiment. The research treatment showed that N, P and K fertilizer can't be reduce by organic fertilizers.
\end{abstract}

Keywords : soybean, multiplecropping, chemical fertilizers, organic fertilizers

\section{PENDAHULUAN}

Tumpangsari merupakan kegiatan menanam beberapa jenis tanaman yang berbeda pada suatu lahan dan waktu yang sama. Sistem pertanian tumpangsari juga dianjurkan sebagai metode untuk meningkatkan total produksi pertanian (Francis 1986 dalam Abd El-Alim et al. 2012). Pertanaman dengan sistem tumpangsari sebaiknya dilakukan pada tanaman-tanaman yang umurnya relatif sama seperti jagung dan kacang-kacangan. Dibandingkan dengan pertanian monokultur, pertanian tumpangsari memiliki kelebihan dalam hal: 1) peningkatan diversitas produk, 2) ketahanan terhadap hama dan penyakit, 3) peningkatan efisiensi tenaga kerja, lahan dan penyerapan sinar matahari, dan 4) mengurangi risiko kerugian ketika salah satu hasil tanaman tidak baik. Pola pertanaman tumpangsari menghendaki ketersediaan unsur hara yang cukup. Kebanyakan petani menyiasati hal ini dengan penggunaan pupuk kimia dalam jumlah besar. Pupuk anorganik meningkatkan hasil pertanian pada awal penggunaannya, akan tetapi hasil panen akan berkurang pada tahun-tahun berikutnya dan tanah menjadi tidak subur. Kekurangan unsur biologi adalah salah satu penyebab berkurangnya kesuburan tanah (Parnata 2004).

\footnotetext{
1) Undergraduate Student of Study Program of Agrotechnology, Faculty of Agriculture University of Sebelas Maret (UNS) in Surakarta

2) Lecturer of Study Program of Agrotechnology, Faculty of Agriculture University of Sebelas Maret (UNS) in Surakarta
}

Contact Author: supriyono_uns@yahoo.com
Perubahan sistem pertanian dari pertanian anorganik ke pertanian organik tidak bisa dilakukan atau dirubah dalam sekali waktu. Perubahan sistem tersebut harus dilakukan secara bertahap. Pemberian pupuk organik mampu menambah bahan organik yang terdekomposisi dan nutrisi untuk tanaman. Pupuk organik mampu meningkatkan sifat fisik tanah secara baik (Nasef et al. 2004, Palada et al. 2004, Khalid dan Shafei 2005). Dalam jangka panjang, pupuk organik diharapkan akan mampu menggantikan penggunaan pupuk kimia secara menyeluruh untuk mencapai pertanian berkelanjutan.

\section{METODE PENELITIAN}

Penelitian ini dilaksanakan pada bulan Februari sampai Mei 2013 di Pusat Penelitian Lahan Kering Fakultas Pertanian Universitas Sebelas Maret Surakarta, Kecamatan Jumantono, Kabupaten Karanganyar. Lokasi penelitian terletak pada $7^{0} 30^{\prime} \mathrm{LS}$ dan $110^{\circ} 50^{\prime}$ BT dan ketinggian tempat 180 meter di atas permukaan laut ( $\mathrm{m} \mathrm{dpl}$ ) dengan jenis tanah Alfisol. Bahan penelitian yang digunakan adalah benih kedelai varietas Anjasmoro, benih jagung varietas Bisma, pupuk organik fine compost, pupuk Urea, pupuk $\mathrm{KCl}$ dan pupuk SP-36. Alat penelitian yang digunakan adalah cangkul, papan nama, meteran, ember, patok, tugal, tali rafia, timbangan, alat tulis, kamera dan oven.

Penelitian ini menggunakan Rancangan Acak Kelompok Lengkap (RAKL) dengan satu faktor yaitu pemupukan yang terdiri dari 6 taraf pemupukan, satu kontrol dan dua pembanding monokultur. Perlakuan diulang sebanyak 4 kali sehingga terdapat 36 petak penelitian. Taraf perlakuan pemupukan adalah sebagai berikut: 
$\mathrm{P} 0=$ Pupuk organik fine compost $0 \mathrm{~kg} \mathrm{ha}^{-1}+$ pupuk urea $150 \mathrm{~kg} \mathrm{ha}^{-1}$ + pupuk SP-36 $100 \mathrm{~kg} \mathrm{ha}^{-1}+$ pupuk KCl $100 \mathrm{~kg} \mathrm{ha}^{-1}$ pada sistem tumpangsari

$\mathrm{P} 1=$ Pupuk organik fine compost $800 \mathrm{~kg} \mathrm{ha}^{-1}+$ pupuk urea $125 \mathrm{~kg} \mathrm{ha}^{-1}$ + pupuk SP-36 83,33 $\mathrm{kg} \mathrm{ha}^{-1}+$ pupuk $\mathrm{KCl} 83,33 \mathrm{~kg} \mathrm{ha}{ }^{-1}$ pada sistem tumpangsari

$\mathrm{P} 2=$ Pupuk organik fine compost $1600 \mathrm{~kg} \mathrm{ha}^{-1}+$ pupuk urea $100 \mathrm{~kg} \mathrm{ha}^{-1}+$ pupuk SP-36 $66,66 \mathrm{~kg}$ $\mathrm{ha}^{-1}+$ pupuk $\mathrm{KCl} 66,66 \mathrm{~kg} \mathrm{ha}^{-1}$ pada sistem tumpangsari

$\mathrm{P} 3=$ Pupuk organik fine compost $2400 \mathrm{~kg} \mathrm{ha}^{-1}+$ pupuk urea75 kg ha-1 + pupuk SP-36 49,99 kg $\mathrm{ha}^{-1}+$ pupuk $\mathrm{KCl} 49,99 \mathrm{~kg} \mathrm{ha}^{-1}$ pada sistem tumpangsari

P4= Pupuk organik fine compost $3200 \mathrm{~kg} \mathrm{ha}^{-1}+$ pupuk urea $50 \mathrm{~kg} \mathrm{ha}^{-1}+$ pupuk SP-36 $33,33 \mathrm{~kg}$ $\mathrm{ha}^{-1}+$ pupuk $\mathrm{KCl} 33,33 \mathrm{~kg} \mathrm{ha}^{-1}$ pada sistem tumpangsari

$\mathrm{P} 5=$ Pupuk organik fine compost $4000 \mathrm{~kg} \mathrm{ha}^{-1}+$ pupuk urea $25 \mathrm{~kg} \mathrm{ha}^{-1}+$ pupuk SP-36 $16,67 \mathrm{~kg}$ $\mathrm{ha}^{-1}+$ pupuk KCl $16,67 \mathrm{~kg} \mathrm{ha}^{-1}$ pada sistem tumpangsari

$\mathrm{P} 6=$ Pupuk organik fine compost $4800 \mathrm{~kg} \mathrm{ha}^{-1}+$ pupuk urea $0 \mathrm{~kg} \mathrm{ha}^{-1}+$ pupuk SP-36 $0 \mathrm{~kg} \mathrm{ha}^{-1}+$ pupuk $\mathrm{KCl} 0 \mathrm{~kg} \mathrm{ha}^{-1}$ pada sistem tumpangsari

$\mathrm{K} 0=$ Pupuk urea $25 \mathrm{~kg} \mathrm{ha}^{-1}+$ pupuk SP-36 $100 \mathrm{~kg}$ ha 1 + pupuk KCl $50 \mathrm{~kg} \mathrm{ha}^{-1}$ pada sistem monokultur

$\mathrm{J} 0=$ Pupuk urea $350 \mathrm{~kg} \mathrm{ha}^{-1}+$ pupuk SP-36 $150 \mathrm{~kg}$ $\mathrm{ha}^{-1}+$ pupuk $\mathrm{KCl} 100 \mathrm{~kg} \mathrm{ha}^{-1}$ pada sistem monokultur.
Tahap-tahap pelaksanaan penelitian meliputi analisis tanah awal, analisis pupuk organik, persiapan bahan tanam, persiapan lahan, penanaman, pemeliharaan dan pemanenan. Pengamatan penelitian meliputi tinggi tanaman, jumlah polong tongkol ${ }^{-1}$ per tanaman, jumlah biji per polong tongkol ${ }^{-1}$, berat 1000 biji, hasil biji per petak, berat segar brangkasan dan berat kering brangkasan.

Data yang diperoleh dianalisis dengan uji $\mathrm{F}$ taraf $5 \%$. Apabila terdapat beda nyata pada perlakuan dilanjutkan dengan uji Duncan Multiple Range Test (DMRT) pada taraf kepercayaan 95\%.

\section{HASIL DAN PEMBAHASAN}

\section{Pertumbuhan dan Hasil Kedelai}

Kedelai merupakan tanaman semusim dengan tinggi berkisar antara $10-200 \mathrm{~cm}$ tergantung pada varietas tanaman. Batang kedelai berbentuk semak rendah dan dapat tumbuh 3-6 cabang pada batang (Zulkarnaini 2010).

Tanaman kedelai menunjukkan respon pertumbuhan yang sama pada setiap perlakuan seperti yang terlihat pada Gambar 1. Ketersediaan nutrisi yang baik untuk tanaman adalah faktor utama bagi pertumbuhan tanaman. Akan tetapi, tingkat pertumbuhan tanaman dipengaruhi pula oleh faktor genetik tanaman. Benih tanaman dengan sifat genetik yang baik akan tumbuh dengan baik pada lingkungan yang tercukupi nutrisinya. Tanaman kedelai berasosiasi dengan bakteri Rhizobium japonicum pada bintil akarnya. Asosiasi ini memungkinkan tanaman kedelai mentransfer nitrogen pada tanaman sereal yang ditumpangsarikan (Banik et al. 2006).

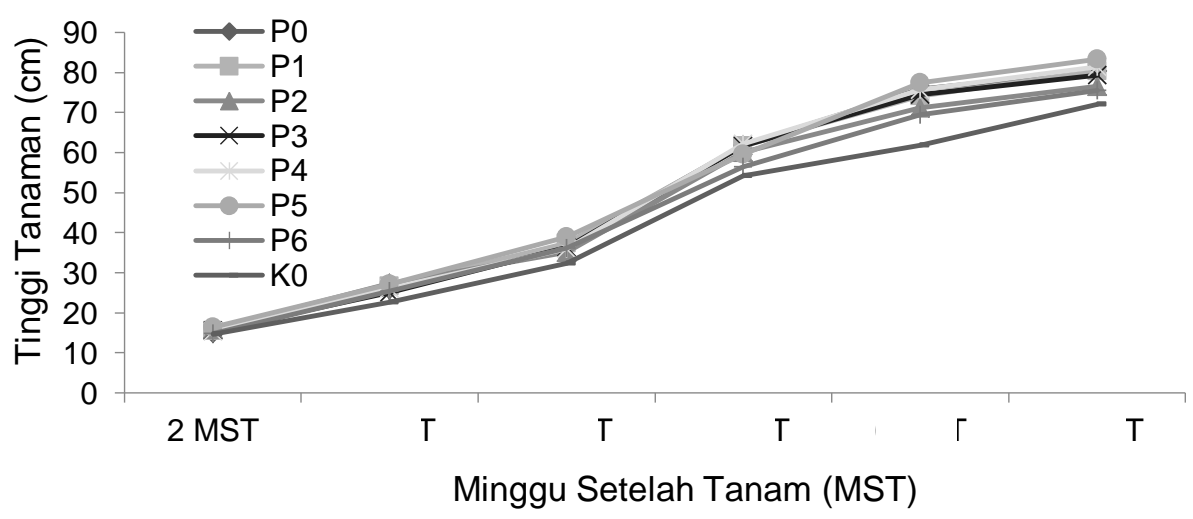

Gambar 1. Pola pertumbuhan tinggi kedelai pada sistem pertanaman tumpangsari

Analisis ragam pada Tabel 1 menunjukkan bahwa perlakuan pemupukan tidak berpengaruh nyata terhadap tinggi tanaman. Rata-rata tinggi tanaman terendah adalah pada perlakuan K0 (Urea $25 \mathrm{~kg} \mathrm{ha}^{-1}$, SP-36 $100 \mathrm{~kg} \mathrm{ha}^{-1}$ dan $\mathrm{KCl} 50 \mathrm{~kg} \mathrm{ha}^{-1}$ ) yaitu 72,05 $\mathrm{cm}$. Rata-rata tinggi tanaman terbesar adalah petak P5 (pupuk organik $4000 \mathrm{~kg} \mathrm{ha}^{-1}$, Urea $25 \mathrm{~kg} \mathrm{ha}^{-1}, \mathrm{SP}$ -
$3616,67 \mathrm{~kg} \mathrm{ha}^{-1}$ dan $\mathrm{KCl} 16,67 \mathrm{~kg} \mathrm{ha}^{-1}$ ) yaitu 83,30 $\mathrm{cm}$. Suplai hara yang cukup membantu terjadinya proses fotosintesis dalam tanaman menghasilkan senyawa organik yang akan diubah dalam bentuk ATP saat berlangsungnya respirasi, selanjutnya ATP ini digunakan untuk membantu pertumbuhan tanaman. 
Tabel 1. Komponen pertumbuhan dan hasil kedelai pada pemupukan yang berbeda

\begin{tabular}{lccccccc}
\hline Perlakuan & $\begin{array}{c}\text { Tinggi } \\
\text { Tanaman } \\
(\mathrm{cm})\end{array}$ & $\begin{array}{c}\text { Jumlah } \\
\text { Polong } \\
\text { per } \\
\text { Tanaman }\end{array}$ & $\begin{array}{c}\text { Jumlah } \\
\text { Biji per } \\
\text { Polong }\end{array}$ & $\begin{array}{c}\text { Berat } \\
1000 \text { biji } \\
(\mathrm{g})\end{array}$ & $\begin{array}{c}\text { Hasil Biji } \\
\text { per Petak } \\
(\mathrm{g})\end{array}$ & $\begin{array}{c}\text { Berat Segar } \\
\text { Brangkasan } \\
(\mathrm{g})\end{array}$ & $\begin{array}{c}\text { Berat Kering } \\
\text { Brangkasan } \\
(\mathrm{g})\end{array}$ \\
\hline K0 & $72,05^{\mathrm{a}}$ & $37,80^{\mathrm{ab}}$ & $2,25^{\mathrm{a}}$ & $144,77^{\mathrm{a}}$ & $1423,00^{\mathrm{a}}$ & $22,06^{\mathrm{a}}$ & $8,99^{\mathrm{a}}$ \\
P0 & $80,40^{\mathrm{a}}$ & $44,75^{\mathrm{ab}}$ & $2,24^{\mathrm{a}}$ & $139,86^{\mathrm{a}}$ & $1361,90^{\mathrm{a}}$ & $27,13^{\mathrm{a}}$ & $18,91^{\mathrm{a}}$ \\
P1 & $80,40^{\mathrm{a}}$ & $51,05^{\mathrm{bc}}$ & $2,31^{\mathrm{a}}$ & $147,33^{\mathrm{a}}$ & $1367,90^{\mathrm{a}}$ & $25,87^{\mathrm{a}}$ & $10,13^{\mathrm{a}}$ \\
P2 & $76,50^{\mathrm{a}}$ & $33,85^{\mathrm{a}}$ & $2,28^{\mathrm{a}}$ & $140,60^{\mathrm{a}}$ & $1335,90^{\mathrm{a}}$ & $16,89^{\mathrm{a}}$ & $6,63^{\mathrm{a}}$ \\
P3 & $79,40^{\mathrm{a}}$ & $42,65^{\mathrm{ab}}$ & $2,29^{\mathrm{a}}$ & $142,80^{\mathrm{a}}$ & $1180,40^{\mathrm{a}}$ & $19,72^{\mathrm{a}}$ & $8,34^{\mathrm{a}}$ \\
P4 & $81,50^{\mathrm{a}}$ & $61,80^{\mathrm{c}}$ & $2,17^{\mathrm{a}}$ & $141,78^{\mathrm{a}}$ & $1311,20^{\mathrm{a}}$ & $25,05^{\mathrm{a}}$ & $9,98^{\mathrm{ab}}$ \\
P5 & $83,30^{\mathrm{a}}$ & $42,50^{\mathrm{ab}}$ & $2,16^{\mathrm{a}}$ & $139,03^{\mathrm{a}}$ & $1286,80^{\mathrm{a}}$ & $22,45^{\mathrm{a}}$ & $8,17^{\mathrm{a}}$ \\
P6 & $75,45^{\mathrm{a}}$ & $41,70^{\mathrm{ab}}$ & $2,16^{\mathrm{a}}$ & $141,05^{\mathrm{a}}$ & $1098,90^{\mathrm{a}}$ & $19,90^{\mathrm{a}}$ & $8,04^{\mathrm{a}}$ \\
\hline
\end{tabular}

Angka yang diikuti huruf yang sama tidak berbeda nyata pada taraf $5 \%$.

Kombinasi pupuk organik dan anorganik berpengaruh nyata terhadap jumlah polong per tanaman seperti terlihat pada Tabel 1. Perlakuan P2 (pupuk organik $800 \mathrm{~kg} \mathrm{ha}^{-1}$, Urea $125 \mathrm{~kg} \mathrm{ha}^{-1}, \mathrm{SP}$ $3683,33 \mathrm{~kg} \mathrm{ha}^{-1}$ dan $\mathrm{KCl} 83,33 \mathrm{~kg} \mathrm{ha}^{-1}$ ) memiliki ratarata jumlah polong per tanaman terendah yaitu 33,85 polong per tanaman. Rata-rata jumlah polong per tanaman tertinggi terdapat pada perlakuan P4 (pupuk organik $3200 \mathrm{~kg} \mathrm{ha}^{-1}$, Urea $50 \mathrm{~kg} \mathrm{ha}^{-1}, \mathrm{SP}-3633,33 \mathrm{~kg}$ $\mathrm{ha}^{-1}$ dan $\mathrm{KCl} 33,33 \mathrm{~kg} \mathrm{ha}^{-1}$ ) yaitu 61,8 polong per tanaman. Kandungan $\mathrm{Mg}$ pada pupuk organik membantu proses transportasi fosfat dalam tanaman (Parnata 2004). Fosfat bagi tanaman berperan dalam pembentukan polong dan biji terutama bagi tanaman kacang-kacangan. Suprapto (1992) menegaskan bahwa tanaman kedelai akan menggunakan $\mathrm{P}$ secara maksimal saat tanaman dalam masa pembentukan polong sampai kira-kira 10 hari sebelum biji berkembang penuh.

Perlakuan pemupukan tidak berpengaruh nyata terhadap jumlah biji per polong pada kedelai (Tabel 1). Rata-rata jumlah biji per polong paling banyak terdapat pada perlakuan P1 (pupuk organik $800 \mathrm{~kg}$ $\mathrm{ha}^{-1}$, Urea $125 \mathrm{~kg} \mathrm{ha}^{-1}$, SP-3683,33 kg ha ${ }^{-1}$ dan $\mathrm{KCl} 3,33 \mathrm{~kg} \mathrm{ha}^{-1}$ ) yaitu sebanyak 2,31 biji per polong. Senyawa utama yang dibutuhkan dalam pembentukan biji adalah karbohidrat. Kedelai mendapatkan sumber karbohidrat atau asimilat yang berasal dari polong yang sedang tumbuh. Unsur fosfor mampu meningkatkan proses pembentukan biji. Selain itu, unsur fosfor juga berfungsi untuk proses asimilasi tanaman. Kekurangan unsur fosfor dapat menyebabkan pemasakan buah terlambat, hasil buah atau bij ikurang, bahkan menyebabkan tanaman tidak berbuah.

Berat 1000 biji tiap perlakuan menunjukkan tidak berbeda nyata seperti tampak pada analisis Tabel 1 . Berat 1000 biji terendah adalah pada perlakuan P5 (pupuk organik $4000 \mathrm{~kg} \mathrm{ha}^{-1}$, Urea $25 \mathrm{~kg} \mathrm{ha}^{-1}, \mathrm{SP}-36$ $16,67 \mathrm{~kg} \mathrm{ha}^{-1}$ dan $\left.\mathrm{KCl} 16,67 \mathrm{~kg} \mathrm{ha}^{-1}\right)$. Sementara berat 1000 biji tertinggi adalah pada perlakuan P1 (pupuk organik $800 \mathrm{~kg} \mathrm{ha}^{-1}$, Urea $125 \mathrm{~kg} \mathrm{ha}^{-1}$, SP-3683,33 kg $\mathrm{ha}^{-1}$ dan $\left.\mathrm{KCl}^{-1} 3,33 \mathrm{~kg} \mathrm{ha}{ }^{-1}\right)$. Berat kering biji dipengaruhi oleh senyawa organik yang terkandung dalam biji tersebut. $\mathrm{Cu}$ dalam pupuk membantu metabolisme karbohidrat dan protein yang ada didalam biji. Kandungan karbohidrat, protein dan senyawa lain dalam biji mempengaruhi berat biji. Unsur $\mathrm{N}$ yang terdapat dalam pupuk merupakan penyusun bahan organik dalam biji sehingga pemberian pupuk yang mengandung $\mathrm{N}$ pada tanaman akan meningkatkan berat kering biji.

Berdasarkan Tabel 1, perlakuan pemupukan tidak berpengaruh nyata terhadap hasil biji per petak. Hasil biji per petak tertinggi terdapat pada perlakuan K0 (pupuk Urea $25 \mathrm{~kg} \mathrm{ha}^{-1}, \mathrm{SP}-36100 \mathrm{~kg} \mathrm{ha}^{-1}$ dan KCl $50 \mathrm{~kg} \mathrm{ha}^{-1}$ ) yaitu $1.423 \mathrm{gram}$ per petak. Sementara hasil tertinggi untuk petak tumpangsari adalah pada perlakuan $\mathrm{P} 1$ dengan pemberian pupuk organik 800 $\mathrm{kg} \mathrm{ha}^{-1}$, Urea $125 \mathrm{~kg} \mathrm{ha}^{-1}$, SP-3683,33 $\mathrm{kg} \mathrm{ha}^{-1}$ dan $\mathrm{KCl} 83,33 \mathrm{~kg} \mathrm{ha}^{-1}$ yaitu $1.367,9$ gram per petak. Sementara hasil per petak terendah senilai $1.098,9$ gram yaitu pada perlakuan P6 (pupuk organik $4800 \mathrm{~kg}$ $\mathrm{ha}^{-1}$, Urea $0 \mathrm{~kg} \mathrm{ha}^{-1}, \mathrm{SP}-360 \mathrm{~kg} \mathrm{ha}^{-1}$ dan KCl0 kg ha $\left.{ }^{1}\right)$. Hasil biji per petak tergantung pada banyaknya biji yang terbentuk pada satu lahan. Pembentukan biji dipengaruhi oleh faktor nutrisi, iklim mikro tanaman dan keberhasilan penyerbukan.

Berdasarkan data analisis varians pada Tabel 1, perlakuan pemupukan tidak berpengaruh nyata terhadap berat segar brangkasan. Berat segar brangkasan tertinggi adalah pada perlakuan P0 yaitu pemberian pupuk organik $0 \mathrm{~kg} \mathrm{ha}^{-1}$, Urea $150 \mathrm{~kg} \mathrm{ha}^{-1}$, SP-36100 kg ha ${ }^{-1}$ dan $\mathrm{KCl} 100 \mathrm{~kg}^{-1}$ senilai 27,13 gram. Berat segar terendah terdapat pada perlakuan P2 (pupuk organik $1600 \mathrm{~kg} \mathrm{ha}^{-1}$, Urea $100 \mathrm{~kg} \mathrm{ha}^{-1}$, SP-36 66,66 kg ha ${ }^{-1}$ dan $\mathrm{KCl} 66,66 \mathrm{~kg} \mathrm{ha}^{-1}$ ) yaitu 16,89 gram. Pupuk $\mathrm{N}$ berperan besar dalam pertumbuhan vegetatif tanaman. Selain memperbesar ukuran tanaman, pupuk $\mathrm{N}$ juga meningkatkan jumlah klorofil, daun dan percabangan dalam tanaman (Gasim 2001 dalam Amin 2011). Jumlah klorofil dan jumlah daun yang meningkat menyebabkan proses fotosintesis berjalan dengan baik dan fotosintat yang dihasilkan akan lebih tinggi maka pertumbuhan pun semakin baik.

Pemupukan menunjukkan perbedaan yang mencolok pada beberapa perlakuan. Sebagai contoh antara perlakuan P2 (pupuk organik $1600 \mathrm{~kg} \mathrm{ha}^{-1}$, Urea $100 \mathrm{~kg} \mathrm{ha}^{-1}, \mathrm{SP}-3666,66 \mathrm{~kg} \mathrm{ha}^{-1}$ dan KCl 66,66 
$\mathrm{kg} \mathrm{ha}^{-1}$ ) dan P0 (pupuk organik $0 \mathrm{~kg} \mathrm{ha}^{-1}$, Urea $150 \mathrm{~kg}$ $\mathrm{ha}^{-1}$, SP-36 $100 \mathrm{~kg} \mathrm{ha}^{-1}$ dan KCl $100 \mathrm{~kg} \mathrm{ha}^{-1}$ ). Berat kering brangkasan masing-masing adalah 6,63 gram dan 18,91 gram. Pada fase ini apabila hara $\mathrm{N}$ terserap dengan baik maka pertumbuhan tanaman akan baik pula sehingga banyak fotosintat yang dihasilkan (Sahari 2012).

\section{Pertumbuhan dan Hasil Jagung}

Pola pertumbuhan jagung seperti yang terlihat pada Gambar 2 berangsur naik tiap minggunya dan mulai konstan saat memasuki minggu ke 9 . Pertumbuhan tanaman jagung mengalami pertambahan tinggi yang pesat saat fase vegetatif.

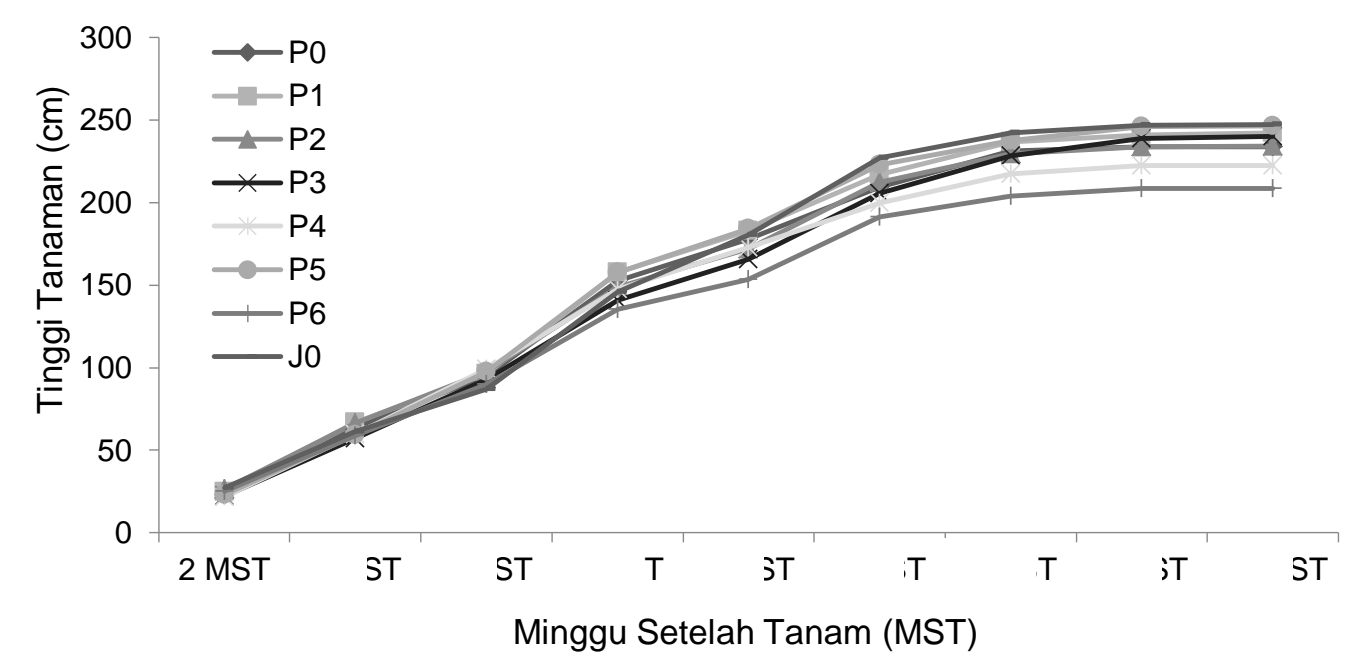

Gambar 2. Pola pertumbuhan tinggi jagung

Perlakuan pemupukan terhadap tinggi tanaman jagung seperti yang terlihat pada Tabel 2 tidak berbeda nyata. Perlakuan J0 (Urea $350 \mathrm{~kg} \mathrm{ha}^{-1}$, SP$36150 \mathrm{~kg} \mathrm{ha}^{-1}$ dan $\mathrm{KCl} 100 \mathrm{~kg} \mathrm{ha}^{-1}$ ) memiliki rata-rata tinggi tanaman terbesar. Varietas Bisma memiliki ketahanan yang unggul pada kekeringan. Tanaman jagung merupakan tanaman yang efisien karena memiliki lintasan fotosintesis C4.
Fase vegetatif tanaman jagung dimulai saat biji berkecambah sampai kemunculan bunga. Unsur yang berperan penting dalam pertambahan tinggi jagung adalah nitrogen. Tanaman jagung yang ditumpangsarikan dengan kedelai mendapatkan unsur $\mathrm{N}$ dari pemupukan Urea. Pada penelitian yang dilakukan terdapat permasalahan tanaman yang ternaungi. Hal tersebut menyebabkan beberapa tanaman mengalami etiolasi. Kerapatan tanaman pada pola tanam tumpangsari adalah salah satu faktor utama yang mempengaruhi pertumbuhan dan hasil tanaman (Meng et al. 2013).

Tabel 2. Komponen pertumbuhan dan hasil jagung pada pemupukan yang berbeda

\begin{tabular}{lcclcccc}
\hline Perlakuan & $\begin{array}{c}\text { Tinggi } \\
\text { Tanaman } \\
(\mathrm{cm})\end{array}$ & $\begin{array}{c}\text { Jumlah } \\
\text { Tongkol } \\
\text { per } \\
\text { Tanaman }\end{array}$ & $\begin{array}{c}\text { Jumlah Biji } \\
\text { per Tongkol }\end{array}$ & $\begin{array}{c}\text { Berat } \\
1000 \text { biji } \\
(\mathrm{g})\end{array}$ & $\begin{array}{c}\text { Hasil Biji } \\
\text { per Petak } \\
(\mathrm{g})\end{array}$ & $\begin{array}{c}\text { Berat Segar } \\
\text { Brangkasan } \\
(\mathrm{g})\end{array}$ & $\begin{array}{c}\text { Berat } \\
\text { Kering } \\
\text { Brangkasan } \\
(\mathrm{g})\end{array}$ \\
\hline J0 & $247,25 \mathrm{a}$ & $1,00 \mathrm{a}$ & $392,65 \mathrm{ab}$ & $318,35 \mathrm{a}$ & $3728,70 \mathrm{~b}$ & $258,04 \mathrm{a}$ & $91,54 \mathrm{ab}$ \\
P0 & $233,88 \mathrm{a}$ & $1,13 \mathrm{a}$ & $462,92 \mathrm{~b}$ & $314,97 \mathrm{a}$ & $1287,90 \mathrm{a}$ & $312,25 \mathrm{a}$ & $102,33 \mathrm{ab}$ \\
P1 & $242,25 \mathrm{a}$ & $1,13 \mathrm{a}$ & $401,75 \mathrm{ab}$ & $294,58 \mathrm{a}$ & $1127,20 \mathrm{a}$ & $221,88 \mathrm{a}$ & $76,57 \mathrm{ab}$ \\
P2 & $234,38 \mathrm{a}$ & $1,00 \mathrm{a}$ & $411,50 \mathrm{~b}$ & $311,70 \mathrm{a}$ & $1069,60 \mathrm{a}$ & $307,75 \mathrm{a}$ & $103,94 \mathrm{ab}$ \\
P3 & $240,00 \mathrm{a}$ & $1,00 \mathrm{a}$ & $383,00 \mathrm{ab}$ & $267,32 \mathrm{a}$ & $1020,20 \mathrm{a}$ & $269,38 \mathrm{a}$ & $97,16 \mathrm{ab}$ \\
P4 & $222,25 \mathrm{a}$ & $1,00 \mathrm{a}$ & $278,88 \mathrm{a}$ & $299,58 \mathrm{a}$ & $959,91 \mathrm{a}$ & $268,12 \mathrm{a}$ & $93,13 \mathrm{ab}$ \\
P5 & $246,25 \mathrm{a}$ & $1,00 \mathrm{a}$ & $398,62 \mathrm{ab}$ & $277,68 \mathrm{a}$ & $793,79 \mathrm{a}$ & $348,50 \mathrm{a}$ & $119,09 \mathrm{~b}$ \\
P6 & $208,50 \mathrm{a}$ & $1,00 \mathrm{a}$ & $333,75 \mathrm{ab}$ & $278,42 \mathrm{a}$ & $942,42 \mathrm{a}$ & $219,12 \mathrm{a}$ & $67,59 \mathrm{a}$ \\
\hline
\end{tabular}

Angka yang diikuti huruf yang sama tidak berbeda nyata pada taraf $5 \%$.

Berdasarkan Tabel 2, pengaruh perlakuan pemupukan tidak berbeda nyata terhadap jumlah tongkol per tanaman. Subekti et al. (2007) menyatakah bahwa pada fase pembentukan tongkol kekeringan dan kekurangan hara sangat berpengaruh
Tinggi tanaman merupakan variabel pertumbuhan tanaman yang paling mudah diamati. Tinggi tanaman menggambarkan efisiensi penyerapan nutrisi oleh jaringan tanaman. Tanaman yang menyerap nutrisi dengan baik akan tumbuh dengan baik pula. Salah satu kenampakan fisik yang paling sering diamati adalah tinggi tanaman. 
Perlakuan pemupukan menunjukkan hasil berbeda nyata terhadap jumlah biji per tongkol (Tabel 2). Pada perlakuan P4 (pupuk organik $3200 \mathrm{~kg} \mathrm{ha}^{-1}$, Urea $50 \mathrm{~kg}$ $\mathrm{ha}^{-1}$, SP-36 33,33 kg ha ${ }^{-1}$ dan $\mathrm{KCl} 33,33 \mathrm{~kg} \mathrm{ha}^{-1}$ ) jumlah biji per tongkol sebanyak 278,88 berbeda nyata dengan perlakuan P2 (pupuk organik $1600 \mathrm{~kg}$ $\mathrm{ha}^{-1}$, Urea $100 \mathrm{~kg} \mathrm{ha}^{-1}$, SP-36 66,66 kg ha ${ }^{-1}$ dan $\mathrm{KCl}$ $66,66 \mathrm{~kg} \mathrm{ha}^{-1}$ ) yaitu 441,50 biji per tongkol dan P0 (pupuk organik $0 \mathrm{~kg} \mathrm{ha}^{-1}$, Urea $150 \mathrm{~kg} \mathrm{ha}^{-1}$, SP-36 100 $\mathrm{kg} \mathrm{ha}^{-1}$ dan $\mathrm{KCl} 100 \mathrm{~kg} \mathrm{ha}^{-1}$ ) dengan jumlah biji per tongkol 462,92. Pemupukan P0 (pupuk organik Okg $\mathrm{ha}^{-1}$, Urea $150 \mathrm{~kg} \mathrm{ha}^{-1}$, SP-36 $100 \mathrm{~kg} \mathrm{ha}^{-1}$ dan $\mathrm{KCl}$ $100 \mathrm{~kg} \mathrm{ha}{ }^{-1}$ ) merupakan perlakuan dengan pupuk Urea tertinggi. Tanaman jagung merespon dengan baik pada perlakuan tersebut. Nitrogen dibutuhkan jagung selama pembentukan tongkol dan pengisian biji. Nugroho et al. (1999), menyatakan bahwa peningkatan bobot tongkol pada tanaman jagung seiring dengan meningkatnya efisiensi proses fotosintesis maupun laju translokasi fotosintat ke bagian tongkol.

Perlakuan pemupukan tidak berpengaruh nyata terhadap berat 1000 biji jagung (Tabel 2). Berat 1000 biji terbaik terdapat pada petak monokultur perlakuan J0 (Urea $350 \mathrm{~kg} \mathrm{ha}^{-1}$, SP-36 $150 \mathrm{~kg} \mathrm{ha}^{-1}$ dan KCl 100 $\mathrm{kg} \mathrm{ha}^{-1}$ ) dengan nilai 318,35 gram. Nilai berat 1000 biji petak tumpangsari terbaik adalah 314,97 gram yaitu pada perlakuan $\mathrm{PO}$ (pupuk organik $0 \mathrm{~kg} \mathrm{ha}^{-1}$, Urea $150 \mathrm{~kg} \mathrm{ha}^{-1}$, SP-36 $100 \mathrm{~kg} \mathrm{ha}^{-1}$ dan $\mathrm{KCl} 100 \mathrm{~kg} \mathrm{ha}^{-1}$ ). Berat 1000 biji terendah adalah 267,32 gram pada perlakuan P3 (pupuk organik $2400 \mathrm{~kg} \mathrm{ha}^{-1}$, Urea $75 \mathrm{~kg}$ $\mathrm{ha}^{-1}$, SP-36 49,99 kg ha ${ }^{-1}$ dan $\mathrm{KCl} 49,99 \mathrm{~kg} \mathrm{ha}^{-1}$ ). Berat 1000 biji berkaitan erat dengan keberhasilan pembentukan biji dan saat panen yang tepat Perlakuan J0 (Urea $350 \mathrm{~kg} \mathrm{ha}^{-1}$, SP-36 $150 \mathrm{~kg} \mathrm{ha}^{-1}$ dan $\mathrm{KCl} 100 \mathrm{~kg} \mathrm{ha}^{-1}$ ) memiliki berat 1000 biji terbesar. Jagung merupakan tanaman yang membutuhkan unsur $\mathrm{N}$ sangat tinggi. Terbukti dari pemupukan dengan dosis urea paling tinggi, hasil berat 1000 biji juga tinggi.

Analisis ragam hasil biji per petak berdasarkan Tabel 2 menunjukkan sangat berbeda nyata. Perbedaan ini terlihat antara semua perlakuan tumpangsari terhadap perlakuan monokultur. Pada pertanaman tumpangsari, hasil jagung dari tiap perlakuan tidak berbeda nyata. Hasil biji per petak terbesar terdapat pada perlakuan PO (pupuk organik 0 $\mathrm{kg} \mathrm{ha}^{-1}$, Urea $150 \mathrm{~kg} \mathrm{ha}^{-1}$, SP-36 $100 \mathrm{~kg} \mathrm{ha}^{-1}$ dan $\mathrm{KCl}$ $100 \mathrm{~kg} \mathrm{ha}^{-1}$ ) yaitu 1287,90 gram dan berat terendah pada perlakuan P5 (pupuk organik $4000 \mathrm{~kg} \mathrm{ha}^{-1}$, Urea $25 \mathrm{~kg} \mathrm{ha}{ }^{-1}$, SP-36 16,67 kg ha ${ }^{-1}$, dan $\mathrm{KCl} \mathrm{16,67} \mathrm{kg}$ ha $^{-1}$ ) yaitu 793,79 gram. Unsur $N$ dibutuhkan dalam jumlah besar untuk pertanaman tumpangsari (Zhao et al. 2011). Ketersediaan nitrogen yang cukup menyebabkan transfer foto sintat untuk pengisian biji meningkat. Oleh karena itu proses pembentukan biji dan pengisian biji berlangsung dengan baik.

Berat segar brangkasan jagung berdasarkan analisis ragam pada Tabel 2 tidak berbeda nyata. Berat segar brangkasan tertinggi terdapat pada perlakuan P5 (pupuk organik $4000 \mathrm{~kg} \mathrm{ha}^{-1}$, Urea $25 \mathrm{~kg}$ $\mathrm{ha}^{-1}$, SP-36 16,67 kg ha ${ }^{-1}$ dan $\mathrm{KCl} \mathrm{16,67} \mathrm{kg} \mathrm{ha}^{-1}$ ) yaitu 348,50 gram. Sedangkan berat brangkasan terendah yaitu 219,12 gram pada perlakuan P6 (pupuk organik $4800 \mathrm{~kg} \mathrm{ha}^{-1}$, Urea $0 \mathrm{~kg} \mathrm{ha}^{-1}$, SP-36 $0 \mathrm{~kg} \mathrm{ha}^{-1}$ dan $\mathrm{KCl}$ $0 \mathrm{~kg} \mathrm{ha}^{-1}$ ). Perlakuan P5 (pupuk organik $4000 \mathrm{~kg} \mathrm{ha}^{-1}$, Urea 25kg ha ${ }^{-1}$, SP-36 16,67 kg ha ${ }^{-1}$ dan KCl 16,67 $\mathrm{kg} \mathrm{ha}{ }^{-1}$ ) memberi hasil yang paling tinggi diduga karena dosis ini adalah dosis yang paling optimal bagi tanaman jagung. Pupuk organik mampu memperbaiki sifat fisik tanah dan memperhara hara esensial dalam tanah (Elhassan et al. 2011). Menurut Siavoshi (2011) sebuah penelitian yang dilakukan pada lima tanaman di Jepang menunjukkan bahwa aplikasi bahan organik meningkatkan pertumbuhan akar dan serapan hara, sehingga hasil lebih tinggi.

Berdasarkan Tabel 2, perlakuan pemupukan tidak berpengaruh nyata pada berat kering brangkasan. Akan tetapi, antar perlakuan menunjukkan perbedaan. Berat kering brangkasan tertinggi pada P5 (pupuk organik $4000 \mathrm{~kg} \mathrm{ha}^{-1}$, Urea $25 \mathrm{~kg} \mathrm{ha}^{-1}$, SP-36 16,67 kg $\mathrm{ha}^{-1}$ dan $\mathrm{KCl} 16,67 \mathrm{~kg} \mathrm{ha}^{-1}$ ) dan berat kering brangkasan terendah pada P6 (pupuk organik 4800 $\mathrm{kg} \mathrm{ha}^{-1}$, Urea $0 \mathrm{~kg} \mathrm{ha}^{-1}, \mathrm{SP}-360 \mathrm{~kg} \mathrm{ha}^{-1}$ dan $\mathrm{KCl} 0 \mathrm{~kg}$ $\mathrm{ha}^{-1}$ ) menunjukkan perbedaan yang nyata. Berat kering brangkasan masing-masing perlakuan adalah 119,09 gram dan 67,59 gram. Penelitian dari Budiastuti (2000) menyatakan bahwa fotosintat yang tertimbun pada bagian vegetatif, juga tercermin dalam berat kering brangkasan. Perlakuan kombinasi P5 (pupuk organik $4000 \mathrm{~kg} \mathrm{ha}^{-1}$, Urea $25 \mathrm{~kg} \mathrm{ha}^{-1}$, SP-36 $16,67 \mathrm{~kg} \mathrm{ha}^{-1}$ dan $\mathrm{KCl} 16,67 \mathrm{~kg} \mathrm{ha}^{-1}$ ) memberikan hasil berat kering brangkasan yang tertinggi karena diduga dengan kombinasi tersebut tanamanmampu menyerap zat hara secara optimal.

\section{KESIMPULAN DAN SARAN}

\section{Kesimpulan}

Berdasarkan hasil penelitian yang telah dilakukan dapat disimpulkan bahwa :

1. Imbangan dosis pupuk organik dan anorganik yang cenderung optimal untuk tumpangsari kedelai-jagung adalah P1 (pupuk organik $800 \mathrm{~kg}$ $\mathrm{ha}^{-1}$, Urea $125 \mathrm{~kg} \mathrm{ha}^{-1}$, SP-36 83,33 $\mathrm{kg} \mathrm{ha}^{-1}$ dan $\mathrm{KCl} 83,33 \mathrm{~kg} \mathrm{ha}^{-1}$ ) dengan hasil tertinggi yaitu kedelai 1,52 ton ha ${ }^{-1}$ dan jagung 1,25 ton $\mathrm{ha}^{-1}$. Perlakuan tersebut tidak berbeda nyata dengan perlakuan tumpangsari pupuk anorganik.

2. Pada penelitian tersebut pupuk organik belum sepenuhnya dapat mengurangi peran pupuk N, P dan K.

\section{Saran}

Pemberian pupuk organik pada pertanaman ini belum memberikan hasil yang optimal, oleh karena itu pemberian pupuk organik masih perlu dilakukan pada musim tanam berikutnya.

\section{DAFTAR PUSTAKA}

Abd El-Alim AM, Magdy MS, Mohamed NS, Tamer IAW. 2012. Effect of intercropping corn on egyptian cotton characters. J Cott Sci 16: 210-219. 
Amin MEH. 2011. Effect of different nitrogen sources on growth, yield and quality of fodder maize (Zea mays L.). J Saudi Soc Agric Sci 10: 17-23.

Banik P, Midya A, Sarkar BK, Ghose SS. 2006. Wheat and chickpea intercropping systems in an additive series experiment: Advantages and weed smothering. Europ. J Agric Sci 24: 325-332.

Budiastuti SM. 2000. Penggunaan triakontanol dan jarak tanam pada tanaman kacang hijau (Phaseolus radiatus L.). Agric Sci 2 (2): 59-63.

Elhassan AAM, EI-Tilib AMA, Ibrahim HS, Hashim AA, Awadelkarim AH. 2011. Response of foster grapefruit (Citrus paradisi Macf.) to organic and inorganic fertilization in central Sudan. Annals of Agric Sci 56: 37-41.

Khalid KHA, Shafei AM. 2005. Productivity of dill (Anethum graveolens L.) as influenced by different organic manure rates and sources. Arab Univ. J Agric Sci 13(3): 901-913.

Meng Q, Hou P, Wu L, Chen X. 2013. Understanding production potentials and yield gaps in intensive maize production in China. Field Crops Research 143: 91-97.

Nasef MA, Khalil AA, Ghazal FM, El-Emam. 2004. The residual effect of organic manures with or without bio-fertilizer applied to wheat grown on sandy, calcareous and clay soils on growth and NPK uptake of rocket plants. Egypt J Agric Res 82(2): 235-246.

Nugroho AN, Basuki, Nasution MA. 1999. Pengaruh Pemberian pupuk kandang dan kalium terhadap kualitas jagung manis pada lahan kering. Habitat 10(105): 33-38.

Palada MC, Davis AM, Crossman SMA, Rables C, Chichester EA. 2004. Sustainable crop management practices for improving production of culinary herbs in the virgin island. Acta Hort. 6(29): 289-298.

Parnata AS. 2004. Pupuk organik cair: Aplikasi dan manfaatnya. Depok (ID): Agromedia Pustaka.

Sahari P. 2012. Pengaruh jenis dan dosis pupuk kandang terhadap pertumbuhan dan hasil tanaman Krokot Landa (Talinum triangulare Willd.) IImu-IImu Pertanian Agroland. 16(3): 36-42.

Siavoshi M. 2011. Effect of organic fertilizer on growth and yield components in rice (Oryza sativa L.). J Agric Sci 3(3): 217-218.

Subekti NA, Syarifudin, Efendi R, Sunarti S. 2007. Morfologi tanaman dan fase pertumbuhan jagung. http//:pustaka.litbang.deptan.go.id. Diakses tanggal 15 September 2012.

Suprapto HS. 1992. Bertanam kedelai. Jakarta (ID): PT. Penebar Swadaya.

Zhao BQ. 2011. Results from long-term fertilizer experiments in China: The risk of groundwater pollution by nitrate. Wageningen $\mathrm{J}$ Life Sci 58: 177183.

Zulkarnaini. 2010. Pengaruh iklim terhadap pertumbuhan tanaman kedelai (Glycine max L.). Tasimak 1(1): 7-13. 